\title{
DNA database proposal gets cautious welcome in UK
}

London. The technique of DNA profiling, invented less then ten years ago by Alec Jeffreys, professor of genetics at the University of Leicester in Britain, passed a new milestone last week when the Royal Commission on Criminal Justice (see opposite) advocated a national database containing the DNA profiles of all individuals convicted of serious criminal offences, from burglary to murder.

The proposal has in principle been welcomed by virtually all participants in the British legal system, implicitly acknowledging the power of genetic information to identify criminal suspects. But several groups have raised concerns about the operation of a database, suggesting that framing legislation to put the commission's proposals into effect may be time-consuming.

There are two separate proposals in the air. One is that the police be given powers to retain information obtained from DNA samples from anyone convicted of a serious criminal offence, regardless of whether the DNA evidence is relevant to that offence. Their powers would be extended to, for example, the right to take saliva samples without consent.

The second proposal is that DNA data on individuals arrested but found innocent should also be retained, to enable the police to build up statistical information about the frequency with which particular characteristics appear in the population. But the commission stresses that responsibility for keeping this information, which would be stored anonymously, should be given to an organization entirely independent of the police.

Police forces in England and Wales, which are already building up their own collections of DNA samples, have welcomed the commission's proposal for detailed legislation to set up both types of database.

Scientists involved in DNA profiling, however, point out that rapid evolution of profiling techniques means that careful consideration needs to be given to the most costeffective way of analysing and storing data in a form that will remain compatible with data generated by new analytical techniques as these come along (as well as with foreign databases). "The technology has not settled down yet," says Jeffreys. "It is too early to say what is the right set of markers or the right testing system to have a database which can be used indefinitely into the future."

Perhaps the strongest objections have come from civil liberties groups, based not on criticism of the science involved, but on the uncertainties that still surround both the recognition of individual DNA profiles and interpretation of their statistical significance. Given such uncertainties, a national databank apparently legitimizing the whole technique "may be premature", says John Wadham, legal officer of the civil liberties group Justice.

Ironically, on the day before the commission's report was published, the court of appeal agreed to hear new evidence concerning two men, both of Afro-Caribbean origin, who were convicted of raping a number of students in Manchester in 1990 entirely on the basis of their identification through DNA samples.

In each case, defence lawyers argue that work since then by population geneticists suggests that the chances of a random match between samples taken from the scene of the crime and those provided by the suspects were significantly underestimated. Franklin Sinclair, the solicitor representing one of those appealing against conviction, says that "until these uncertainties are sorted out, DNA profiling should not be accepted in the same way that we accept fingerprints."

But the general feeling is that continuing uncertainties in interpretation do not, in themselves, invalidate the case for a national database. The main priority is to ensure that adequate safeguards are provided for the way in which information is obtained, stored and used.

The royal commission itself has emphasized the need for such safeguards; and the police, who recently decided to destroy 2,000 DNA files because of uncertainty over their status, are keen to have a framework that will protect them from legal challenges.

David Dickson

\section{Challenge to growth hormone trial}

San Francisco. A clinical trial in the United States of human growth hormone in normal children of short stature faces possible shutdown unless the National Institutes of Health (NIH) can show that it complies with federal regulations. A suit filed in late June in US District Court for the District of Columbia argues that the trial violates national rules for using children in clinical studies by needlessly risking patients' psychological and physical health.

The trial is controversial because the children are not deficient in growth hormone. Earlier studies have pointed to a possibility that these patients, after receiving additional hormone, may grow to less than their expected heights of up to 5-feet-6inches as men or 5 feet as women. Critics also have raised questions about physical side-effects and the psychological impact of participating in the placebo arm of a study that could create distress about height.

The NIH suspended the trial last year to consider such questions, but resumed treatment in non-deficient children after two independent panels concluded that widespread use of the drug to treat prospective height-deficiency made growth hormone an important public health issue. They defended the experiment, in spite of what they considered greater than minimal risk for the children, on the grounds that unusual shortness is a pathological condition.

But the panels did warn against cosmetic use of growth hormone and said the study should stop making exceptions to include slightly taller young people than specified in the original protocol.

On 9 July, the Physicians Committee for Responsible Medicine, with 3,400 physician members, and a group led by antibiotechnology activist Jeremy Rifkin, which filed the suit together, demanded of the court documentation supporting the $\mathrm{NIH}$ view. The questions raised centre on the identification of short stature as a condition requiring treatment, NIH records of sideeffects and the agency's relationship with the two manufacturers of the drug. NIH must respond within 45 days.

The NIH has no official comment on the suit, but Michaela Richardson, chief of the office of research reporting for the National Institute of Child Health and Human Development, said the US agency felt compelled to do the study because growth hormone, in spite of its high cost, is in use in some 7,500 non-deficient children and could possibly harm them. "We're not trying to cure shortness or anything like that," Richardson said. "We're just trying to understand whether this drug works so there can be a rational basis to prescribe it or not."

Interestingly, media coverage of the suit has prompted scores of calls from people wanting to join the trial. The NIH intended to enrol 80 short children but has been able to recruit only 36 by referrals from physicians.

The groups who filed the suit argue that the national agency is supporting a social stigma instead of attacking it, and carrying out the will of private drug manufacturers rather than meeting public need. Two companies have enjoyed a growing, and exclusive, market for human growth hormone, which sells for $\$ 20,000$ or more for a year's treatment. Genentech Inc. sold \$205 million of the treatment in 1992. Eli Lilly, which is providing drugs for the NIH trial, sold $\$ 170$ million in the same period.

Both versions of the drug are protected from competition until 1994, when they must find a way to retain market share. The treatment is being studied for other conditions, including osteoporosis and chronic renal insufficiency.

Sally Lehrman 